\title{
The Meanings of Communion: Anglican Identities, the Sexuality Debates, and Christian Relationality
}

\author{
by Robert M. Vanderbeck, Gill Valentine, Kevin Ward, Joanna Sadgrove and Johan Andersson \\ University of Leeds
}

Sociological Research Online, Volume 15, Issue 2,

$<$ http://umw.socresonline.org.uk/15/2/3.html>

$10.5153 /$ sro. 2106

Received: 9 Nov 2009 Accepted: 3 Mar 2010 Published: 20 May 2010

\begin{abstract}
Recent discussions of the international Anglican Communion have been dominated by notions of a 'crisis' and 'schism' resulting from conflicts over issues of homosexuality. Existing accounts of the Communion have often tended to emphasise the perspectives of those most vocal in the debates (particularly bishops, senior clergy, and pressure groups) or to engage in primarily theological analysis. This article examines the nature of the purported 'crisis' from the perspectives of Anglicans in local parishes in three different national contexts: England, South Africa, and the United States. Unusually for writing on the Communion, attention is simultaneously given to parishes that have clear pro-gay stances, those that largely oppose the acceptance of homosexual practice, and those with more ambivalent positions. In doing so, the article offers new insights for the growing body of literature on lesbian, gay, bisexual, and transgender Christians, as well as wider discussions about the contested nature of contemporary Anglican and other Christian identities. Key themes include the divergent ways in which respondents felt (and did not feel) connections to the spatially distant 'others' with whom they are in Communion; the complex relationships and discordances between parish, denominational, and Communion-level identities; and competing visions of the role of the Communion in producing unity or preserving diversity amongst Anglicans.
\end{abstract}

\section{Keywords: Anglican Communion; Sexuality; Christianity; Religious Identities}

\section{Introduction}

1.1 For more than a decade, academic and media representations of the Anglican Communion have been dominated by talk of a 'crisis' and growing 'schism' resulting from seemingly intractable debates over homosexuality within the church (Bates 2004; Clatworthy 2008; Mutter 2004; O'Donovan 2008; Yip and Keenan 2004). At the forefront of these debates has been the Episcopal Church (TEC), which consecrated an openly gay man, Gene Robinson, as bishop of New Hampshire in 2003, raising an outcry from both many self-identified 'orthodox' Episcopalians as well as the primates of a number of the Communion's autonomous provinces. The provinces of Nigeria and Uganda, amongst several others, have declared themselves to be in states of impaired communion with TEC, calling for the US province to repent or be expelled from the Anglican polity. ${ }^{[1]}$ Relationships between provinces have become sufficiently strained that the Archbishop of Canterbury, Rowan Williams, has publicly contemplated the need for a new Communion structure involving an inner circle of provinces who agree to a binding Anglican covenant and a loosely attached outer circle who do not (Williams 2009a, 2009b). A number of disaffected US parishes (along with several from Canada) have broken away to form a competing neo-traditional province-the Anglican Church of North America (ACNA) - and hope to eventually supplant TEC as the recognised expression of Anglicanism within a future covenanted structure. Matters have been further complicated by the Roman Catholic church's recent creation of a path for dissatisfied Anglicans in the Anglo-Catholic tradition to reunify with Rome, with as yet unknown affects on the Communion. ${ }^{[2]}$ In short, it remains a very open question whether the Communion will persist in its present form, and, if not, what sets of relationships might replace it.

1.2 Existing accounts of the Communion have tended to emphasise the perspectives of those most vocal in the debates (particularly bishops, senior clergy, and pressure groups) or to engage in primarily theological analysis. ${ }^{[3]}$ Our aim in this article is explore what being 'in communion' means for Anglicans who have been neither the leading nor most quoted voices in the ongoing debates. Specifically, we examine the nature of the purported crisis within the Communion from the perspectives of Anglicans in a selection of local parishes in three different national contexts: England, South Africa, and the USA. Unusually for writing on the Communion, we simultaneously give attention to parishes that have clear pro-gay stances, those that 
largely oppose the acceptance of homosexual practice, and those with more ambivalent positions. Our analysis offers important insights to both the growing body of literature on lesbian, gay, bisexual, and transgender Christians (e.g. McQueeney 2009; Thumma and Gray 2005; Wilcox 2006; Yip 1997; Yip 2005) as well as wider discussions about the contested nature of contemporary Anglican and other Christian identities (e.g. Ammerman 2003; Hassett 2007; Hoad 2007; Pickard 2008).

1.3 Claims about the nature of the Communion have been made both by those who seek to radically restructure it (such as those who would expel provinces with 'unorthodox' views on homosexuality) and those who hope to preserve its current form. Prominent conservative commentators, for example, have often accused TEC of not caring about its relationships with and responsibilities to the Communion. Chris Sugden (2008) has argued that the US church is engaged in a 'deliberate flouting of Christian teaching and (the) decisions of the whole Anglican Communion and its leadership.' Similarly, the Bishop of Durham, Tom Wright, has equated TEC's disregard for international opinion to that shown by George W. Bush's presidential administration in conducting the invasion of Iraq (Gledhill and Combe 2008). In reply, leaders of the US church have asserted that the province has 'an abiding commitment' to the fellowship and encourages 'dioceses, congregations, and members of (TEC) to participate to the fullest extent possible in the many instruments, networks and relationships of the Anglican Communion. ${ }^{[4]} A$ commission appointed by the Archbishop of Canterbury has declared that the Communion is so important that membership requires 'putting the needs of the global fellowship before (one's) own'. [5] The Archbishop himself argues that 'the Communion... matters massively' (Williams 2007) while, at the same time, calling for members to work on deepening their relationships:

'(W)e've discovered that our relations with each other as local churches have often been strained, that we haven't learned to trust one another as perhaps we should, that we really need to build relationships, and we need to have a sense that we are responsible to one another and responsible for each other' (Williams 2009b).

1.4 Do Anglicans at the parish level share this sense of urgency about the importance of the Communion and the need to deepen the relationships that constitute it? Do they worry about schism or perceive a 'crisis'? In what ways do they feel connections with, and responsibilities to, those spatially distant others with whom they are in communion? Although these are questions that have significance for understanding both the current state and potential future trajectory of the Communion, they have rarely been the subject of empirically grounded research. Our analysis of qualitative data from six parish level case studies offers new perspectives on these questions and, in the process, raises broader issues about the complexity of contemporary Anglican identities. Before proceeding to our empirical discussion, however, we first set the research in context and outline the approach to data collection and analysis.

\section{Being in communion: Anglicanism and the sexuality debates}

2.1 Although it is now common to refer to the 'worldwide' or 'global' Anglican Communion, it is important to recognise the comparatively recent vintage of this construction (see Ward 2006 for a fuller history). As anthropologist Miranda Hassett (2007: 253) notes, 'Many speak of current controversies as if they were tearing up an established, settled way of being a global Communion', when in fact the Communion has been very much an evolving project. The first of the decennial Lambeth Conferences of Anglican bishops was convened in 1867; however, only since about the 1960s - a period that corresponds with African decolonization - have there emerged concerted efforts to produce a fellowship that exhibits a 'high degree of interconnectedness and mutual awareness' (Hassett 2007: 253). Notions of a 'worldwide' or 'global' Communion have gained currency in parallel with the growing recognition of the need to chart a postcolonial future for Anglicanism in which all of the Communion's provinces fully participate. Questions about Anglicanism's postcolonial identity vex many Anglican commentators who wonder if, and how, the various local manifestations of Anglicanism can maintain a sense of unity across sometimes significant differences, and, furthermore, how the bases for this unity can be produced in ways that do not privilege the voices of the wealthier provinces of the global North (e.g. Douglas and Pui-Lan 2001).

2.2 No issue has seemingly challenged the bases for commonality as much as homosexuality, to the extent that one prominent commentator has wondered 'Is sex going to kill the Anglican Communion?' (Kaye 2007). New transnational alliances have emerged between dissidents in the North and some Southern bishops (particularly in sub-Saharan Africa, but also elsewhere) who have sought to block and reverse moves towards greater acceptance of homosexual relationships. Most notably, this alliance was instrumental in the divisive passage of Resolution 1.10 at Lambeth 1998, which declared homosexual practice to be 'incompatible with scripture' (although like all Lambeth resolutions, it has no binding authority on the provinces). In the subsequent decade, tensions over homosexuality were further stoked by events including the 2003 consecration of Bishop Robinson, the creation of a liturgy for blessing same-sex unions by the Diocese of New Westminster, Canada in 2002, and the practice of blessing same-sex partnerships (whether furtively or openly) in some parishes in the US, UK, and Canada. 
2.3 The strongest international conservative reaction to date has been the organisation in June 2008 of GAFCON (the Global Anglican Future Conference), a group of bishops, clergy, and lay people who 'want to hold on to the Biblical and Historical faith' (Global Anglican Futures Conference 2008; Sadgrove et al, in press). Many of the bishops at GAFCON subsequently boycotted the 2008 Lambeth Conference in July, due to the presence of American bishops who had supported Gene Robinson. Robinson himself was in fact excluded from the conference in an attempt to appease a number of conservative bishops, a move that angered many supporters of gay inclusion within the Communion, including pro-gay Christian campaigning groups such as the Lesbian and Gay Christian Movement, Integrity USA, and Changing Attitude. ${ }^{[6]}$ Although no major new declarations emerged from Lambeth 2008, the final discussion document called on churches to refrain from either consecrating more gay bishops or conducting same sex blessings to avoid the further straining of relationships in the Communion. In 2006, the US church had in fact passed a moratorium known as BO33 that effectively blocked the consecration of openly gay people in hope of deescalating the debate, but this ban was overturned by a large majority at its 2009 General Convention. In the aftermath of this repeal, the Archbishop of Canterbury (although often said to personally favour widened gay inclusion) wrote openly about the need for an Anglican covenant in light of TEC's decisions.

Nevertheless, challenges to the Archbishop of Canterbury's centrality within the Communion continue to become increasingly vocal (e.g. Orombi 2008), with some suggesting that a re-organisation of the Communion is necessary to better represent the voices of the growing numbers of Anglicans in the global South.

\section{Unity in diversity? Conceptualising the Communion}

3.1 In the midst of this highly uncertain landscape, commentators have offered a variety of interpretations of what it means to be 'in communion' and why (or if) this is valuable. Many of these interpretations hinge upon the extent to which uniformity of belief should be either a prerequisite or a goal of communion. MaryJane Rubenstein (2008), for example, explores the relevance of Jean-Luc Nancy's philosophy for understanding recent developments within Anglicanism. Contrasting his notions of a 'common-being' with 'being-in-common', Rubenstein sees recent conservative responses to homosexuality as exemplifying a desire to create the former, with a demand that Anglicans form one Christian 'body'. This desire, in Rubenstein's interpretation, is necessarily accompanied by a fear of 'contamination' by impure elements that may enter-or grow within - this united body. In reaction, attempts are made to block or expel these impurities, in part reflecting St. Paul's injunction 'that believers not associate with openly immoral church members.'.7] Thus, one statement by the Council of African Provinces suggested the need for unity and purity as a condition for interchange: 'Let the Western churches first affirm God's plan for the sexes, then let us dialogue' (quoted in Rubenstein 2008: 158). Rubenstein in contrast professes a hope for Anglicans to build something more akin to what Nancy describes as a 'community', where 'being is understood not as common but in common...(A) community's essence is shared out-communicated, fragmented, shattered' (p. 140, emphasis added). Community in this sense involves taking the risk of potential contamination via ongoing interchange with those with opposing views. Writing in an explicitly theological register, Jenny Te Paa (2009), the dean of Te Rau Kahikatea (College of St. John the Evangelist) in New Zealand, differentiates notions of communion that involve becoming one with the other from those that stress becoming one of the other. In her view, the former tends to be characterised by 'selfless, sacrificial and loving solidarity', while the latter can be a selfish or cynical act that does not allow people 'to become fully whom God created (them) to be and to flourish into that God given identity.' Becoming 'one with' involves dialogue and commitment while also allowing each province to follow its 'contextual spiritual conscience'.

3.2 Echoing this tension between competing visions of unity, anthropologist Miranda Hassett (2007), in her groundbreaking ethnographic account of the links between one US dissident parish and the province of Uganda, identifies two different forms of discourse that she found prominent amongst her interviewees: accountability globalism and diversity globalism. For Hassett (2007: 127), the conservative position is largely characterised by an accountability globalism that 'rests on the concept of worldwide interprovincial accountability to fixed scriptural norms, clarified through intercultural correction, supported and enforced by a global orthodox Anglican majority.' Writing simultaneously as an academic and practicing Anglican, Hassett instead advocates a diversity globalism which she associates with the 'liberal/moderate' position, based on an ideal of 'diversity in unity, understood as sharing Christian fellowship across differences in culture, experience, and belief (p. 127). While Hassett and Rubenstein both seem to hope to preserve (at least in some form) the connections and relationships that the Anglican Communion involves, sociologists Yip and Keenan (2004) argue that a schism could have benefits because of its potential to foster greater pluralisation, which they see as something preferable to compromises made for the sake of maintaining historical unity. In their view, 'the much feared split may result in a Christianity that is more responsive to local cultures', and, as such, might strengthen the long term survival prospects of individual Anglican churches within their particular contexts.

3.3 Each of these commentators offers a particular vision of a future for Anglicanism (see also Harris 1998). Our goal here is neither to adjudicate between them nor to offer our own preferred model. Rather, informed 
by these discussions, we seek to understand how a diverse range of Anglicans 'on the ground' (many of whose perspectives are lost or under-examined in current media and academic discussions) conceptualise the meaning and value of the Communion within the context of the sexuality debates, something which we argue is essential for understanding the future direction of the Communion.

\section{Researching communion}

4.1 Our data are drawn from an international project examining how the provinces of the Anglican Communion are responding to shifting public attitudes about homosexuality; how discourses about homosexuality in one context have been circulated, mobilized, and/or transformed within other contexts; and how new networks of actors are forming to respond to developments in the Communion related to homosexuality. Fieldwork for the project has been conducted in the UK, US, South Africa, Lesotho, and Uganda. Our methods of data collection have included semi-structured interviews with a range of relevant actors (both clergy and laity) across the contexts; observation at key Communion events (including GAFCON in Jerusalem, the 2008 Lambeth Conference, and the 2009 General Convention of the Episcopal Church); and extensive document and media analysis. In total, more than 140 people participated in interviews, as well as many dozens more in less formal interviews and conversations in the field.

4.2 In this article we draw primarily upon a subset of this wider data set involving six case study parishes: two each in the Church of England (COE), the Anglican Church of Southern Africa (ACSA), and TEC, which provide a number of contrasts (see TABLE 1). In each national context, we chose two different parishes within the same broad urban context to explore issues related to the sexuality debates and the Communion. Choosing parishes in the same urban area allowed us to examine not only the international dimensions of communion but also more localized aspects of denominational connection. We make no claim that the case studies are 'representative' of their national or urban contexts, as this was not our goal. Nor have we captured every position, theological stance, or liturgical approach that exists within these contexts, given the well-known diversity of Anglicanism. Rather, these contrasting parishes allow us to explore complexities, ambivalences, emotions, and reactions that are often absent from accounts that foreground the voices of bishops and the most vocal commentators. For our purposes here, our goal is not to present the data in the form of fully articulated individual case studies (an impossibility within the space of one article) but rather to draw out key themes from across the case studies that shed light on the relevant issues.

Table 1. CASE STUDY PARISHES 


\begin{tabular}{|c|c|c|}
\hline Province / National Context & Urban Context & Parishes \\
\hline $\begin{array}{l}\text { Church of England: As societal attitudes } \\
\text { have become more tolerant of homosexuality } \\
\text { (Crockett and Voas 2003), pressure groups } \\
\text { have emerged within the church who support } \\
\text { or oppose these changes. Although not yet } \\
\text { experiencing TEC's level of division, there } \\
\text { are growing worries about 'holding the } \\
\text { tension' between differing segments of the } \\
\text { church over issues of homosexuality as well } \\
\text { as female ordination. There are also } \\
\text { divisions over COE's responses to England's } \\
\text { changing legal context (e.g. civil partnership } \\
\text { and anti-discrimination legislation). }\end{array}$ & $\begin{array}{l}\text { Urban area in the } \\
\text { north of England }\end{array}$ & $\begin{array}{l}C O E-1 \text { : A predominantly white parish } \\
\text { with a mixed working-class and } \\
\text { middle-class congregation. The parish } \\
\text { has a relatively high proportion of } \\
\text { LGBT members, and a reputation for } \\
\text { engaging with social justice issues. } \\
\text { COE-2: An ethnically mixed parish, } \\
\text { largely Afro-Caribbean and white with } \\
\text { a growing presence of African } \\
\text { refugees. Considered relatively high } \\
\text { church. Issues related to } \\
\text { homosexuality were not often } \\
\text { discussed openly. }\end{array}$ \\
\hline $\begin{array}{l}\text { Anglican Church of Southem Africa: South } \\
\text { Africa is by far the largest member of } \\
\text { ACSA. Anglicans account for about } 4 \% \text { of } \\
\text { South Africans. The country is known for } \\
\text { having the first constitution prohibiting } \\
\text { discrimination based on sexual orientation. } \\
\text { However, surveys suggest that a substantial } \\
\text { majority of people hold negative views about } \\
\text { homosexuality (Robert and Reddy } 2008 \text { ). } \\
\text { The leadership of ACSA have espoused } \\
\text { generally supportive views on } \\
\text { homosexuality, although it has been cautious } \\
\text { about gay marriage. }\end{array}$ & $\begin{array}{l}\text { Urban area in the } \\
\text { Kwa-Zulu Natal } \\
\text { region }\end{array}$ & $\begin{array}{l}\text { ACSA-1: A predominantly Zulu parish } \\
\text { in a township area. Homosexuality } \\
\text { was not often discussed openly in the } \\
\text { congregation, although there was at } \\
\text { least one 'out' member. The style of } \\
\text { worship was high church. } \\
\text { ACSA-2: A predominantly white, } \\
\text { middle class parish. The church has a } \\
\text { 'broad church' style and diverse views } \\
\text { on homosexuality. Homosexuality was } \\
\text { not much discussed and did not feature } \\
\text { often in sermons. }\end{array}$ \\
\hline $\begin{array}{l}\text { The Episcopal Church: Episcopalians } \\
\text { account for a relatively small proportion } \\
\text { (less than } 2 \% \text { ) of Americans. The sexuality } \\
\text { debates have been particularly divisive for } \\
\text { TEC. In } 2008 \text {, dissident parishes/dioceses } \\
\text { claiming about } 100,000 \text { members formed the } \\
\text { ACNA, which hopes to gain recognition by } \\
\text { the Communion. In } 2009 \text { TEC lifted a } \\
\text { temporary ban (put in place in } 2006 \text { ) on the } \\
\text { elevation of openly gay people to the } \\
\text { episcopacy. }\end{array}$ & $\begin{array}{l}\text { Metropolitan area } \\
\text { of a large city in } \\
\text { the northem USA }\end{array}$ & $\begin{array}{l}\text { TEC-1: A predominantly white, } \\
\text { middle class parish with a substantial } \\
\text { gay, lesbian, and bisexual presence. } \\
\text { The liturgical style was a blend of } \\
\text { Catholic and evangelical styles of } \\
\text { worship. } \\
\text { TEC-2: A predominantly white but } \\
\text { ethnically mixed congregation with an } \\
\text { evangelical profile The parish has } \\
\text { been at odds with its diocese about the } \\
\text { direction of the Episcopal Church. }\end{array}$ \\
\hline
\end{tabular}

4.3 The six case study parishes (see Table 1) were situated in quite different ways in relation to the sexuality debates. These issues were a relatively prominent focus of discussion in COE- 1 and TEC-1, the two conspicuously gay friendly parishes, as well as in TEC-2, which had significant reservations amongst its evangelical parishioners about the theological direction of the wider U.S. church. In COE-2, ACSA-1, and ACSA-2, these issues were much less publicly discussed and did not feature often in sermons, with clear indications in all three parishes that there was discomfort in some quarters with talking about homosexuality. Particularly in COE-2 and ACSA-2, clergy freely acknowledged avoiding raising the debates for fear that they would divide their congregations, and they feared a scenario where their parishes might have to 'choose sides' in the event of continued conflict at the Communion level.

4.4 Over a fourteen month period in 2008-2009, we conducted both individual and group interviews with congregation members in each case study parish, adhering to protocols of informed consent. Group interviews had between five and eight participants. We also interviewed the vicars/rectors of the parishes and, where possible, additional clergy members. An average of twelve respondents participated in interviews in each parish. One or more members of the team attended multiple Sunday services (a minimum of five services at each parish) and other activities at each of the parishes. This allowed us to meet members of the congregation and witness the style of worship. Attending services and other activities 
also provided opportunities to recruit participants for individual and group interviews in a face-to-face way. ${ }^{[8]}$

4.5 Of necessity, approaches to recruiting varied somewhat between the parishes, although we strived to include a range of voices from within each parish. Over the course of the research, we gave consideration to the diversity of views that were being expressed in each context, where necessary seeking out parishioners who might offer a different perspective from the dominant story that was emerging at each site. Typically, the researcher was introduced to the congregation by a member of the clergy (often by way of an announcement during or after a church service). Parishes varied in the extent to which the vicar or rector sought to act as gatekeepers to parishioners, thus having some potential influence on the nature of the sample (particularly for the organisation of group interviews). Clergy were most active in this regard at ACSA-1 and COE-2; however, a range of views were expressed in all contexts, suggesting that where parish clergy facilitated focus group recruitment, it did not lead to the expression of a singular 'party line' (especially in ACSA-1, parishioners in fact offered a number of views on the nature of contemporary Anglican identity that contradict those of the vicar, although most shared the vicar's broadly conservative stance on issues of homosexuality). Perhaps inevitably, parishioners who chose to participate in the study tended to be reasonably regular attendees with a degree of involvement in church activities outside of Sunday services, although few had much (if any) involvement in diocesan or national church affairs.

4.6 The lead author thematically coded the individual and group interview data for the purposes of this article, consulting closely with other team members about issues of interview context, language, and meaning to ensure that respondents' voices are represented and interpreted fairly. ${ }^{[9]}$ The analysis involved the use of both 'in vivo' codes which draw upon terms used by the informants themselves and analytical codes developed by the researchers from preliminary readings of the interviews. The codes from individual accounts were compared to generate dominant and counter themes. All names used in the analysis are pseudonyms. ${ }^{[10]}$

4.7 The remainder of the article proceeds as follows. We first explore how respondents' formed their (sometimes strong) views about current events in the Anglican world whilst holding substantial uncertainties about the nature of the Anglican Communion and how it was governed. We then examine the differential levels of investment that respondents had in the idea of being 'in communion' with other Anglicans (and other Christians more broadly), followed by a discussion of the often emotionally charged ways in which respondents thought about the merits of their relationships with those with opposing views. This leads to a consideration of individual commitments to the notion of Anglican identity, including the complex relationships and discordances between commitments to parishes, provinces, and the wider Communion. We also examine how some respondents invoked a form of 'accountability globalism' that involved staying in communion with-rather than expelling - those with opposing views on homosexuality. We then offer some concluding remarks and thoughts on future directions for research.

\section{The nature of communion: 'I never quite know....'}

5.1 Before exploring the multiplicity of ways in which meaning was (or was not) attributed to the Communion, it is important to recognise how knowledge about current events within Anglicanism varied widely within and across the case study sites. Simply put, many parishioners had marked uncertainties about the nature of the Communion to which they belonged, and they often openly discussed these uncertainties. While particular contours of the sexuality debates were commonly known across contexts (such as the existence of a 'gay bishop' in the US, something widely reported in the media in all three national contexts), the nature of the Anglican polity proved the source of a number of questions and misunderstandings. As one respondent in the English parish COE-1 remarked, "I never quite know (where) the authority structure lies in the Anglican church." At a fundamental level, although parishioners often articulated feelings of sadness in relation to the damaged relations within the Communion (as we elaborate below), there was often ambiguity about who even composed the Communion. While many respondents discussed how 'African' bishops were championing a 'traditional' position on homosexuality-with Archbishop Peter Akinola being the figure most commonly invoked, either by name or simply as the 'bishop from Nigeria'-relatively few respondents (including in the South African parishes) had detailed awareness of which specific African provinces were involved. Provinces in Asia, Latin America, Australia, and New Zealand were rarely invoked in the interviews and did not seem to be imagined as significant actors in the conflict (this in large part seems to echo the common framing by the popular media of the sexuality debates as a struggle between African and North American provinces).

5.2 Parishioners not infrequently asked questions about the emerging scenarios for 'schism' and how their parish might be affected ('What would a split entail?, I mean what, how?', as one respondent from ACSA-2 asked). In the South African parish ACSA-1, the relatively recently appointed vicar had felt the need upon his arrival to give his parishioners lessons regarding the episcopal 'authority structures' of Anglicanism given his perception that they knew little about the Anglican polity (although, as he discussed, these lessons were prompted more by insecurities about his own authority within the parish - given that the congregation 
had deposed a number of prior vicars - rather than concerns about the state of the Communion). Even in the three parishes with the clearest investments in the trajectory of the sexuality debates (COE-1, TEC-1, and TEC-2), respondents sometimes expressed guilt or regret for not understanding more about the perspectives of people in other parts of the Communion. As Charlotte (a heterosexual member of TEC-1 who was studying for ordination) noted when discussing the reactions of other provinces to recent moves by TEC, 'I haven't followed it deeply and I'm embarrassed that I haven't deeply followed it.'

5.3 We call attention to this realm of uncertainty not as a way of critiquing the geographical or religious knowledge of respondents, but rather for two specific reasons. First, although not uniformly the case, these expressions of uncertainty gesture towards the relative lack of immediacy that relationships in the Communion (as compared to those in their local parishes or, in some cases, dioceses) held for most respondents. Events in the Communion of course had implications locally, but parishioners rarely engaged with issues at the Communion level as such, with these engagements being seen primarily as an activity for bishops. Second, feeling uncertain about the lives of Anglicans in other provinces contributed to the ambivalences that a number expressed when discussing emerging divisions within the Communion. Respondents who articulated strong opinions about the sexuality debates and the positions of other provinces not infrequently later qualified these views with a recognition that they had little unmediated information about the perspectives of the people about whom they spoke. As one white female respondent at U.S. parish TEC-1 explained with some distress in relation to the anti-gay pronouncements emerging from the Church of Nigeria:

HELEN: I think it's very difficult for me because I don't know these people. All I know is what I read in the paper, and I know what I read in the paper is so horrible, but I don't know these human beings. I just know [that] I don't know what they've been through. ${ }^{[11]}$ (group interview)

5.4 Nevertheless, the feeling that one had an incomplete grasp of the debates did not necessarily mean that respondents did not hold strong opinions about issues or deep (sometimes conflicted) feelings about what they perceived as happening in the Communion. In the next section, we examine in greater detail how parishioners perceived both the Communion and the emerging divisions within it.

\section{'Tearing apart the body of Christ'}

6.1 While respondents discussed the meaning and value of the Communion in diverse ways, few saw it as holding the importance attributed to it in the rhetoric of the more prominent champions of either preserving or urgently re-organising the Communion. A frequent position, articulated by a selection of respondents in all six case study parishes, was that being in relationship with Christians in other places was important, but that local affairs were paramount. For example, parishioners at English parish COE-2 indicated that a divide in the Communion had significance to them, but nevertheless felt that life in their parish would not be much affected. Denise, a retired Afro-Caribbean woman who showed ambivalences about discussing issues of homosexuality (citing her father's view that 'God made Adam and Eve, not Adam and Steve', provoking laughter from several others in the group interview) thought that a schism would matter to her because 'united we stand, divided we fall'; however, her primary example of how this would affect her involved the discomfort she might feel when visiting another Anglican church when travelling abroad (rather than any direct impact locally). Melinda, a retired white female in the same parish, similarly suggested that the local impacts would be minimal, but that a fracturing of the Communion would nevertheless be a source of sadness.

MELINDA: I think it would be very sad if (schism) happens but [...] I think it's almost inevitable because the bishops between them can't sort this out, can they? [....] Were it to happen, I think we would go on very much as we are now, because, at the end of the day, what we're most interested in is our own little patch and the way we live our own individual lives, and the broader picture doesn't really affect us from day to day. But as a whole I think it would be very sad. But I think it's inevitable.

INTERVIEWER: (W)hat do you think you would lose? Why would it be sad? What would you lose by that?

MELINDA: Well we would lose this whole concept of unity and communion, wouldn't we....

OTHER RESPONDENTS (overlapping): That's right. Yes, indeed.

MELINDA: Which is a very important thing.

(group interview)

6.2 In this account, what would be lost is a 'concept of unity and communion' rather than active relationships with any 'day to day' reality. Those who had opportunities for international travel (such as 
Denise) sometimes recounted experiences of having visited churches elsewhere that gave them a greater sense of the wider Anglican 'family', but (with a few exceptions of those with relatives living abroad) these experiences were not ones that forged interpersonal relationships that might be damaged by schism. For Denise, Melinda, and many others across the parishes (whether liberal, conservative, or otherwise), the Communion existed primarily as a 'concept' or abstraction, and although parishioners felt varying degrees of regret about potential schism, this did not often equate with a clearly articulated or deeply felt allegiance to the institutional arrangements of Anglicanism.

6.3 Some respondents more explicitly identified the 'concept' that would be lost as that of a universal Christian church - the idea that Christians should be one catholic body of believers. In the South African parish ACSA-2, Matt (a relatively young white male who was planning to study for ordination) articulated a sense of sadness at the 'tearing apart... of the body of Christ' that he saw as taking place. This sadness, however, did not reflect any broader commitment to the necessity of preserving the Anglican polity as such. $\mathrm{He}$ (part facetiously) saw value in the potential travel opportunities afforded to him through Communion membership, but ultimately the Communion itself mattered little.

MATT: Any tearing apart of the church and of the body of Christ is, I think, a very sad thing [...] (The Anglican Communion) actually doesn't have a whole lot of significance for me [....] I mean, people here are interested in it, but it's not the be all and end all of their lives, you know [....] I suppose knowing that the Anglican Church is all over the world makes me think whoa, Jesus, it might be quite nice once I'm ordained to see if I can [laughs] go somewhere else for a year. You know, I love South Africa; I wouldn't want to leave forever, but just for the experience of going somewhere different. That's appealing, so it's kind of quite a selfish [...] thing. Erm, but other than that, it actually doesn't have a whole lot of significance for me, erm, yeah. (individual interview)

6.4 Although he expressed generally supportive views about gay and lesbian inclusion, he felt ambivalent about the consecration of Gene Robinson ('I'm fairly liberal, but even I'm not so sure about that') and thought that the intensity of the sexuality debates in some quarters was substantially out-of-proportion to their importance. This ambivalent position was invoked by a number of other respondents in ACSA-2, where issues of sexuality were not often openly discussed in the congregation. Within the parish, perspectives on the Communion were diverse, with a number suggesting on initial response that the Anglican Communion as such was unimportant, but on further exploration identifying regrets about the potential split of Christians that any schism would represent. As one group interview respondent answered unequivocally (with nods of agreement from several others) when asked what the Communion meant to her: 'Absolutely nothing (group laughter).... I mean, do I look to Canterbury?' Another noted that she thinks of herself as 'a Methodist converted to Anglicanism' and, as such, the Communion 'doesn't mean anything to me.' Nevertheless, as the conversation progressed, the group collectively identified a number of potential regrets, such as the 'loss of that tradition and that sense of sharing [...] The common tradition throughout the world just goes.' As another respondent also worried, 'it would be particularly unfortunate to have a Third World / First World split. It would be particularly nasty, so we just don't want to do that. ${ }^{[12]}$ At the same time, however, several respondents invoked racialised imaginative geographies (Vanderbeck 2006) that saw the conflict as one between 'modern' and traditional' societies because 'in your Ugandas and your Nigerias, you're living in a culturally traditionalist society in all its forms of patriarchy, etc. and that is what's being played upon. ${ }^{[13]}$

6.5 While some ACSA-2 parishioners emphatically did not 'look to Canterbury', others felt a particular sense of connection to the Church of England, with less concern about other provinces. For example, Doris (who held theologically conservative views on homosexuality and its ecclesiological implications, but who nevertheless supported gay inclusion due to the experience of a family member 'coming out') felt meaningfully connected to the Church of England for reasons of migration history, but not to other places. Despite explicitly noting that she felt no connection with the U.S. or other African provinces, she nevertheless thought that a potential split in the Communion represented a 'distressing' loss of something 'very solid and secure'-too reminiscent for her of previous internal divisions within South African Anglicanism (see Lewis 2007). However, as expressed by both clergy and several lay people at ACSA-2, the parish had difficulty generating active interest in linkages with other parishes even within their own diocese, no less with other parts of the Communion (with a parish twinning project with a North American church having failed due to lack of parishioner involvement). As Elizabeth (a retired heterosexual woman who played an active role in the parish) described it:

ELIZABETH: I think most people don't bother about going to anything but their local church anyway. Occasionally, when (there is) a function at the cathedral and they want us all to go, some of us will go, but not very many because we'd rather go to our parish church, we're comfortable there [...] and I think that's probably the same in England or anywhere else in the world that you don't think globally but you like to, you like to be global. (individual interview, emphasis added) 
6.6 This sense of appreciating the global identity of the Communion while not having much interest in actively engaging in relationships beyond the parish was exemplified by Elizabeth's fellow parishioner Tom (a straight-identified white male in his thirties), who spent little time thinking about the wider affairs of the Anglican polity but who nevertheless liked feeling part of something bigger than a single parish. Membership in the Communion differentiated his parish from stand alone charismatic churches, which, having attended one briefly himself (despite being raised as an Anglican), he looked upon with some disdain:

TOM: I notice that so many (charismatic churches) will be non-affiliated to anything or perhaps loosely affiliated, but they largely are a stand alone, but so many of them tack 'International' onto the end of their names [....] It's about ego, it says, 'we're great and [...] we have the true meaning of Christianity' and $[\ldots]$ they quote $[\ldots]$ a few verses about going forth to Jerusalem, Judea and the rest of the world really [...] (W)hereas I think to be part of a, I mean, do you know, I don't think of the broader context other than to say 'well, all we are is, is, is one level on a broader thing' and it's actually more humbling. (Individual interview)

6.7 Although he liked the 'humbling' experience of being part of an international denomination, events and relationships in the 'broader context' of the Communion were not felt with any immediacy. In other cases - particularly in parishes with more clearly defined positions on homosexuality (whether liberal or conservative)-being in Communion with those with differing standpoints provoked a much stronger set of emotions.

\section{'If you feel like that, get lost...'}

7.1 At both COE-1 and TEC-1 (the two parishes with conspicuous 'pro-gay' profiles), the sexuality debates had far greater local currency than at ACSA-2, where the issues were not often discussed publicly. Given their high proportions of lesbian, gay, and bisexual parishioners, condemnations of homosexuality by other provinces were felt both more personally and more viscerally. A frequently expressed position at COE-1 and TEC-1 was that being embedded in a broader set of relationships with other parishes had worth, but that maintaining these relationships could not involve a violation of the integrity of their own positions. Louise, who had a female partner and some involvement with diocesan-level politics, suggested that although some members of her parish would 'go to the edge' before agreeing to a split (including herself, who she identified as 'more Anglican' than many members of COE-1 who cared less about denominational issues), the parish had an identity that was stronger than denominational loyalty.

LOUISE: I mean, I feel if push came to shove, (this parish) has a very strong sense of its own identity and isn't particularly bothered about the Anglican Communion so if (necessary) would leave the Anglican community [...] I mean, how that would work practically I have no idea. And there would be a strong fight from a lot of people not to do that [...] If the Anglican Communion came down like a ton of bricks on (us) that would crack (our parish) away, but there are a lot of people who would go to the edge before that happens. (individual interview)

7.2 For Louise, there were valuable things about the Communion as a concept ('I suppose it's history and culture and something to keep prodding me out of parochialism'), but the gay affirming position of her parish was not something she or most others were willing to compromise in the name of unity with other provinces or, for that matter, within the Church of England. Like Louise, several members of both COE-1 and TEC-1 imagined the Communion as providing challenges to their own established ways of thinking about issues. Although they experienced strong emotions in relation to the homophobia they perceived from 'conservative' voices both outside and within their own provinces, they attempted to find value in being in touch with those with opposing views. As one gay male member of COE-1 explained (with agreement from several others), he experienced moments of hostility towards the 'arch-fundamentalists', but then returned to a position of wanting to be a part of a 'broad' Anglican Communion with a diversity of perspectives.

TIMOTHY: I think there have been times when I thought about the GAFCON people and the arch-fundamentalists, 'well, if you feel like that, get lost.' That's, that's not what I really feel because I think the beauty of the Anglican Communion is that it's a broad church, and we have to have the breadth of theology and experience and churchmanship and our perspective on faith [....] Otherwise, you know, if we're content to let one wing go, erm, you know, it diminishes all of us and we're left with a narrower church. (group interview)

7.3 Similarly, Richard (a relatively young gay male at COE-1) had deeply conflicted feelings about being in Communion 'with people who think that I am an abomination'. He sometimes wished that the 'liberal' church wouldn't push issues in a way that alienated conservatives, and other times wanted to cut ties altogether with those with anti-gay views. Below he elucidates his thoughts about the nature of interconnectedness in the Communion, explaining that, in an increasingly global world, the statements of those in one province can damage the faith of those far away. 
RICHARD: I sort of alternate between feeling that it's very important that we stay in Communion with people and then asking myself just why I feel like I should stay in Communion with people who think that I'm an abomination. And I'm not really settled on a specific view, but when I'm thinking we should try and stay in Communion I actually find myself thinking that the church, the progressive church, the liberal church, should actually slow down and wait for the conservatives to keep up, rather than thinking we should force the conservatives to speed up to our speed. (M)y thinking behind that is that when the church was taken to Africa by the missionaries, there was actually a very, very conservative theology which was taken to the African people, and it took the church in the West a thousand years to get over that so why should we expect people to speed up, to go through 800 years of, of spiritual development and growth just because we're in a completely different place to them. Erm, but then [...] I also think that it's still wrong and the world we're living in now (is) such an interconnected world that there's no place to be 800 years behind [...] and that the speeches that a bishop in, in, in Algeria or South Africa (will make) an impact on the church in England. Er, so I do feel it's important to be part of a [...] world Communion, erm, but I don't feel like there's any point carrying that on for indefinitely if people can't start to agree. And I think, well, the other thing I feel about the Anglican Communion is that [...] a diversity of views is good, er, as long as those views don't actually become destructive and I think we're at a stage now where [...] they're beginning to destroy, and not just destroy the church as a Communion but to destroy individuals [...] What these people are saying (is) actually damaging people here's relationship with God. (individual interview)

7.4 Precisely because the world has become so interconnected, Richard thought it might be undesirable for his parish or province to maintain relationships with those who are 'behind', propagating views that damage his own faith. However, while recognising the historical impact of European missionizing (Ward 2006), Richard drew upon representations of African societies as 800 years behind the 'liberal church' in terms of 'spiritual growth and development' (while also tracing recent anti-gay discourse in the Communion, problematically, to South Africa and Algeria. $)^{[14]}$ Connections with African bishops, in his view, had the real effect of disrupting the sense of comfort he experienced in his own parish within the Church of England. However, the converse belief that choices about gay inclusion made in the US or England had an impact in African churches was explicitly rejected by some parishioners in COE-1 and TEC-1. As one gay male at TEC-1 noted with some anger, 'The American Episcopal Church...ordaining Bishop Gene Robinson doesn't affect a thing in Nigeria', followed by the suggestion that the US church should stop sending mission funding to anti-gay churches in retribution. ${ }^{[15]}$

7.5 This sense that decisions by the American church did not affect life in other places was far from uniformly shared by respondents in the predominantly Zulu-speaking parish ACSA-1, many of whom emphasised that they felt that the decisions of TEC had a strong impact on the reputation of Anglicanism within their township. Several parishioners, as well as the vicar, expressed admiration for other African provinces-particularly Nigeria-that were perceived to be taking a more 'biblical' perspective on the sinfulness of homosexuality, viewing the failure of their own province to take a strong anti-gay stance as a blow to the status of Anglicans relative to Methodists, charismatics, and other competing churches 'where they take the Bible as the word of God as it is'. As Bongi, a middle age woman, asserted:

[In South Africa] sexual orientation is now in the open, people are doing it openly, but still it is still a taboo subject in the church. I've never been exposed to a sermon where this was addressed as a church [nor have I seen] a church taking a stand to say, 'As Anglicans we say no!'. Or we say 'Mmmm, maybe.' I don't know where we stand as Anglicans in terms of this....Me, as an individual, I'm saying 'no' to this, but as a church, we're not saying where we stand.

7.6 This view was echoed by ACSA-1's vicar, who indicated that if the South African church were to eventually authorise the practice of same-sex marriage, he would consider giving up his license to conduct marriages and might open his own, independent evangelical ministry. ${ }^{[16]}$

7.7 Group interview respondents in ACSA-1 suggested in limited ways that the Anglican Communion itself had some importance, but generally struggled to identify any specific advantages of their relationships with Canterbury or other provinces. As Thabile (a retired woman and member of the Mothers' Union) indicated when asked if she thought the Communion was significant, 'I do think, for whatever reason, I don't know. I think it is important, though I don't really know what it is that we benefit as a result [group laughter]' (group interview). In the views of a number of respondents at ACSA-1, though, there were clear disadvantages to the guilt-by-association that being linked to the U.S. church ostensibly carried. For some, the sexuality debates had contributed to a questioning of their own denominational loyalties. In the next section, we explore in greater detail this relationship between perspectives on Communion events and broader commitments to Anglican denominational identity. 
'This parish happens to be Anglican...'

8.1 Within ACSA-1, denominational identity was a complex matter, involving struggles within the parish over what it meant to be Anglican and how the parish should be positioned in relation to other churches in the township, particularly Methodist and Pentecostal churches. South Africa's stark racial divides substantially influenced how the congregation perceived Christian relationality, with relationships with other black Christians in the township seemingly prioritised over those with predominantly white Anglican churches in their own diocese. Several suggested that they worshipped in an Anglican church because that had been the tradition in their families, but felt little commitment to a denomination. Below, Thabile discusses her perspectives on Anglican identity, suggesting that although she once felt a stronger commitment to Anglicanism, she now considered denominational identity to be a secondary matter:

THABILE: For me, being an Anglican doesn't mean anything to me.

INTERVIEWER: Really?

THABILE: Yes. I'm no longer influenced by being an Anglican. I'm influenced by the word of God.

INTERVIEWER: Ok. But you're still coming to the Anglican....

THABILE Well, as family. As a worshiping family. Yes.

INTERVIEWER: I suppose that's the better question. The better question is what does it mean to you all to be an Anglican? Does it mean anything?

THABILE: No. It doesn't mean anything. It's just that we belong to the Anglican Community.

8.2 This view was reiterated by Bongi and Khawulani (a middle aged man), who suggested that loose commitment to Anglican identity was a mark of being on a personal spiritual journey that had 'taken a step up' from denominational loyalties and liturgical preferences for seeing 'this, that, and that' during worship services.

BONGI: [Anglicanism] is just a home.

INTERVIEWER: Do you all feel the same?

KHAWULANI: It's the surname. ${ }^{[17]}$ [group laughter]

INTERVIEWER: So it's no different from being a Methodist or Pentecostal?

BONGI: But I think this will depend on the level of spirituality of an individual. Others, they really feel very strongly about being Anglican. When they go into church they really want to see this, that, and that which makes this church an Anglican one. But if your spirituality has taken a step up, then you know that God is above Anglicanism. It depends on the level of [...] the relationship that you have with God. (group interview)

8.3 If the affirmation of homosexual relationships in parts of the Communion was seen by a number of ACSA-1 respondents as tarnishing Anglicanism's reputation and damaging member recruitment, the gay inclusive profiles of both TEC-1 and COE-1 have served to attract a number of converts from both Roman Catholicism and Protestant traditions. For some of these, their Anglican affiliation was the result of biographical factors and personal relationships that had led them to a particular parish in which they found comfort, support, and community, with denominational structures and conflicts meaning little beyond their impacts upon the congregation. Suzanne, for example, is a straight-identified woman and former Roman Catholic who strongly supported gay inclusion at COE-1, and had joined the parish in large part because of its progressive reputation. Despite being very active in parish affairs, she noted 'I'm not a person who's going to General Synod', reflecting her lack of interest in denominational politics. She discussed her views on the Communion in the following terms, expressing her linked impatiences with those who opposed female leadership in the Communion and those who advanced homophobic views. ${ }^{[18]}$

SUZANNE: (B)ecause of the structures, it means that everything takes such a bloody long time, and I get really angry at the idea that we bend over backwards to support these men who think that we can't have women leaders in the church. And I, you know, I just think, 'oh, let them go.' Let them go do what they like and I feel the same way about [...] the gay issue, it's like if people want to be homophobic, great, let them go and do it somewhere else, you know, we don't have to be like that. It's completely impractical, you can't, you couldn't run an institution like that so... 
INTERVIEWER: Well, no, but I mean [...] if there was a split for example...?

SUZANNE: I wouldn't care. But then I don't know enough about the structures of the thing to care. I don't care about the institution really, you know, I'm not bothered [....] (This church) happens to be Anglican and if it had been something else, I guess that's where l'd have been, you know. (individual interview)

To Suzanne, her church simply 'happens to be Anglican', with denomination being incidental to her sense of her own or the parish's identity.

8.4 This does not suggest, however, that this view was universally shared amongst converts, with several respondents having been drawn to Anglicanism precisely because of its international character and sense of being a 'universal' church. Scott, for example, is a formerly devout Roman Catholic who attended TEC-1. A decade ago he had made the painful decision to convert to a church with a more progressive stance on homosexuality, feeling that he could no longer wait for the Vatican to change. As he described it, while some gay and lesbian parishioners joined TEC-2 specifically because of the profile of the parish or the Episcopal Church, Scott was concerned about being part of a church that had a sense of universality and interconnectedness.

SCOTT: Many (people I know who come here) were just joining (this specific parish), and then (there are) many for whom the Episcopal Church was an important thing. But, to me, it was very important that I was joining the Anglican Communion [...] I was coming from a universal church and I wanted a universal church [.... One of the weird things about (this parish), I guess it's not weird, it's, within the Episcopal Church is that people do all sorts of things differently [....] (W)e have some very traditional people who like, you know, lift their head every time the word Jesus Christ is said, and there's some people who cross themselves all the time and some people who don't cross themselves at all. And at a certain point I decided to start opening my hands when I say the Our Father. Nobody else does that, I mean, priests do this. Erm, and I do this because I know that [...] a lot of evangelicals do it and [...] to me it's really important at that moment to try and remember every other person who is saying those words [...] I try to connect to more than (this parish) and more than the Episcopal Church and more than the vanguard (of Christian gay activists). (individual interview)

8.5 Even though many parishioners at both TEC-1 and COE-1 were less taken by the idea of the Anglican Communion than Scott, this did not necessarily imply a lack of interest in engaging with the world beyond their parish. The Anglican Communion was but one of many channels - and not necessarily the most important or valued one-for demonstrating a Christian commitment to people in other places. For example, at COE-1, parishioners frequently described their active and visible involvement in campaigns against the invasions of Afghanistan and Iraq as a way of showing a Christian sense of care for the wider world. At TEC-1, the bulk of the parish's charitable effort was directed at services for local homeless people but, in the words of their rector, they did not see a schism as something that precluded building more extensive international involvements.

INTERVIEWER Would there be any impact at all on your day to day parish life if you were (no longer part of the Communion)?

RECTOR: Probably not a lot [...] because I think we would find other ways to connect with issues and concerns in other parts of the world [...] We have people who've travelled a lot abroad. We have someone who just came back from the Middle East in a parish (there), we were involved with some projects around women in (Central Africa), you know, we supported an HIV project in (Southern Africa), so it's, it's something that we would care about. l'd like us to find to find something that's a more sustained connection actually because I think it would do us good to have that relationship. (individual interview)

8.6 Conservative commentators have often accused theologically liberal parishes of having little concern for the fate of the Communion. However, at TEC-2-where parishioners largely identified as 'evangelical' and 'conservative' in their theological (although not necessarily political) orientations-commitments to the wider Communion and Anglican identity in many respects seemed to parallel those in the more 'liberal' parishes. As a result of the consecration of Gene Robinson, TEC-2 had a strained relationship with its diocese, although the current majority sentiment was to remain within the Episcopal Church despite these differences (in part due to questions about whether the parish really wanted to align itself with the breakaway parishes in the US). In contrast to the theologically conservative parish examined by Hassett (2007) — where none of her respondents reported knowing a single gay person-interviewees at TEC-2 all reported personally knowing people with an LGBT identity, given the visible presence of gays and lesbians within their urban context. 
8.7 As proved true in the other case study parishes, a number of parishioners spoke about the idea of Communion as a potentially 'nice' concept while simultaneously expressing limited commitment to its structures. Although many were attracted by the more liturgical style of TEC-2 compared to the nonliturgical style of many US evangelical churches, their discussion of their religious identities reflected the broader tendency in the US for evangelicals to prioritise evangelical commitment over denominationalism (Smith 1998). For example, Mona (a white female in her fifties) was a self-identified evangelical who considered herself to be one of the more progressive members of the congregation on issues of homosexuality (she supported the idea of gay marriage, although not all that vocally). Not a 'cradle Episcopalian', Mona had become very active in TEC-2 through a close friend and stayed because she liked the parish's style of worship and evangelical outlook. ${ }^{[19]}$ She cared little about denominational politics or the Communion, likening the Communion to an exercise in singing 'Kumbaya' (a well-known and oftridiculed folk song):

INTERVIEWER: Okay. Are you still invested in the idea of being part of the Episcopal Church and maybe even more broadly being part of the Anglican Global Church?

MONA: Am I personally? I'm not invested in it. In other words, I don't care. I don't care about this denomination stuff [...] I feel like I happened into the Episcopal Church and [...] this (parish) is actually the place to be because the people seem to really be thinking here in a way that sings for me.

INTERVIEWER: And the Anglican Worldwide Communion, not at all?

MONA: I haven't really thought about it. It's a nice idea [laughs]. It's a nice idea that everybody's going to hold hands and sing 'Kumbaya', but you know what, I think there's always going to be division. So I'm kind of, like, it would be nice [...] but I don't know if I'm particularly invested in it all staying together as one big [pause] It's too bad for there to be these divisions.

8.8 Similarly, fellow parishioner David (who resisted the conflation of his evangelical identity with political conservatism) had a weak attachment to notions of Anglicanism and international communion. Before moving to this diocese, he had been involved in non-denominational 'low churches' (by his description), but was attracted to the liturgical traditions and practices at TEC-2. The extensive level of involvement that he had with parish activities, however, belied his generally low levels of commitment to either the Communion or broader Anglican identity.

INTERVIEWER: Are you invested in the idea of the Anglican Communion? Is it important for you to be part of this global network?

DAVID: No. Like, personally, no. Like theologically and like, you know, the church being connected and accountable and part of a global community, I think it's important. And the Anglican Communion and others, the Catholic Church, do that. So I'm a fan of that. But me personally, if I were to leave (this urban area), my wife and I have talked about this, would I necessarily go to an Episcopal or Anglican church? Not necessarily. Yeah. So I'm not [pause] So yeah, that's the long and short of it. (individual interview)

In certain respects, David found connectedness and global accountability attractive, but nevertheless felt uncommitted to attending another Episcopal church if he were to move to another city, being very open to worshiping in other denominations.

\section{'The hope that we might be able to change them'}

9.1 Although he did not elaborate on the idea, David's notion of accountability was invoked by a number of other parishioners at TEC-2. However, in contrast to some forms of 'accountability globalism' discussed by Hassett (see above), the discourse of a number of members of TEC-2 tended to simultaneously identify the Communion as a potential vehicle for holding people to account for their decisions while also emphasising that members of the Communion had to stay in dialogue for this to happen. Thus, rather than the Communion expelling those who support full gay inclusion in the church (as is advocated by a number of prominent conservative voices), the Communion should be attempting to 'call them back to the centre of the Gospel'. As Adrian at TEC-2 expressed:

ADRIAN: I think that being in an Episcopal church, (the global Communion) has been very helpful for me [...] because in North America in the last 30 years, the Episcopal Church has been notoriously liberal and strayed from the historical Christian faith. And so in a sense it's easy to write off those people and say they've started their own sect/cult that is not Christian, but being within it is a reminder that we're part of a family [...] that who name in the name of Christ, whether Roman Catholic, Episcopal, Methodist, Lutheran, whatever, it is part of this 
family and that we are responsible to one another and that we're responsible for calling one another to account, which is what I think is happening in the Anglican community. That by virtue of being part of this Communion and part of this larger church body, we can't just write off people with whom we disagree, but have to respectfully engage and call people back to the centre of the gospel. (individual interview)

9.2 For Adrian, being part of the Communion had been cognitively important because he could imagine himself as part of a wider international denomination where he believed most other members shared his theological perspective (even if this was not the case at the scale of his province). Not wanting to 'write off theological liberals who might be viewed as creating a new 'sect' or 'cult', Adrian saw the Communion as a means of returning people to the fold-but seemed unambiguous that the leadership of the Episcopal Church had strayed from a defensible path when it consecrated Gene Robinson. The interchanges that come from being in communion with others are thus envisioned as a means to guide people back to the 'historic' faith, rather than a means for producing new understandings as a result of ongoing interchange.

9.3 However, although recognised as useful in this respect, the role of the Communion as a mechanism for accountability did not necessarily make it actively valued by parishioners. lan, a white male who did not think that the church should affirm 'homosexual expression', appreciated the Communion as a means of preventing churches from being too easily 'guided....by culture', but nevertheless saw the value of the Communion in primarily 'theoretical' terms:

INTERVIEWER: So you don't feel that connected to the international Communion in that sense?

IAN: I mean I certainly followed it and with some interest, but, yeah, no, I don't feel hugely connected to it [....] (T)o the extent the Episcopal Church is held accountable by the wider communion, I also think that's really valuable. That way it prevents any church from being purely kind of just guided by its culture and the cultural trends in that country [....] But that's more just [pause] These are theoretical commitments, you know....I don't feel deeply [committed] to the Episcopal Church.

9.4 This belief that the Communion could serve as a vehicle for influencing other parts of the Church was not restricted to evangelical respondents at TEC-2, with some members of the two churches with clear progay profiles, COE-1 and TEC-1, expressing a largely analogous view. For Timothy at COE-1, despite his sense of anger at the statements of the leaders of the Nigerian church, the notion of communion required being 'generous': 'I've actually got to take that risk of allowing bigots in, in the hope that we might be able to change them.' Liam (a straight-identified priest at COE-1) discussed in even stronger terms how he hoped to stay in touch with 'the evangelical wing' of the Church for their sake as much as his.

LIAM: I felt very sad for the [...] evangelical wing of the church here and overseas in that it's a group of people who've lost sight of baptism and [...] who seem to be more concerned with a form of religious ethnic purity that I think is quite foreign to the Gospels [....] As I see it, the international kind of evangelical stuff and some of the Nigerian stuff in particular, phew, is, is caught up in what Jesus I think spent most of his time trying to coax people out of.

INTERVIEWER: Are you in communion with Peter Akinola? Do you want to be in communion with him? Or would you prefer a kind of orderly split?

LIAM: I would like to find a way of being in communion with him because I think he needs us. Because I think if that wing of the church is allowed to suggest gay promiscuity is in any way different from straight promiscuity, $x x$ it's in that sense hell bound [...] so if there was any glimmer of linkage and leaning and fellowship there l'd want to try and keep that alive [....] To have a blind spot that big is, is spiritually soul hurting, so I kind of want to stay in touch with them really, and maybe they've got bits that are important for us to pay attention to. (individual interview)

9.5 Describing evangelical Christian views as 'unbiblical' and 'hell bound' (a rare explicit invocation of the concept of hell in our interviews), Liam argued that they 'need us', while also acknowledging that there might be things his parish could learn from the 'evangelical wing'. Thus, while there is an openness to a degree of interchange, staying in communion from this perspective is primarily oriented towards healing the soul-hurting 'blind spot(s)' of those with opposing views.

\section{Conclusion: imagining interconnectedness}

10.1 In this article, we have examined the nature of the 'crisis' in the Anglican Communion from the perspectives of parishioners and clergy in case study parishes located in England, South Africa, and the U.S.A. We have given particular attention to the significance that differently positioned respondents, with a 
range of views on the sexuality debates, attributed to the Communion. As we have argued, although views on the Communion varied, relatively few respondents attributed it with the importance suggested by the tone of much recent public discourse about the impending threat of a permanent 'schism'. While many respondents expressed degrees of sadness about divisions between and within provinces, this sadness was often explained in terms of the potential loss of more abstract notions of tradition, memory, history, and a universal Christian church, rather than a deep sense of commitment to the current institutionalised arrangements of international Anglicanism. As concisely summarized by one respondent (section 6), 'You don't like to think globally but you...like to be global', gesturing towards the ways in which many respondents valued being part of an international Christian body without feeling motivated to actively develop the 'high degree of interconnectedness and mutual awareness' (Hassett 2007: 127) championed in some Communion quarters.

10.2 A number of respondents nevertheless expressed complicated, nuanced, and often discordant emotions regarding (their perceptions of) recent events in the Communion. For respondents in the parishes with strong pro-gay commitments, the public statements of leaders of the GAFCON movement were a source of considerable anger and frustration. As Richard and others indicated (section 6), the growing interconnectedness of the world meant that public statements circulated quickly and had the power to wound. Thus, although membership in a universal church (while not always expressed with exactly that term) was broadly considered an important principle across the case studies, certain kinds of Christian interconnectedness were viewed as undesirable. In some cases, white respondents' perceptions of the (un)desirability of staying in communion with conservative Africans-'your Nigerias and Ugandas', to recall the phrase of one white South African respondent (section 5) - were inflected with racialised understandings of these provinces and their leaders as relatively 'behind' the times. For many of the more conservative respondents, the actions of TEC were to varying degrees perceived as impacting upon the reputation of Anglicanism, offering some challenge to (recently retired) South African Archbishop Njongonkulu Ndungane's assertion that, 'I interact with people on the ground. They don't care about the lifestyles of people in America' (quoted in Rubenstein 2008: 155). Although not necessarily deeply invested in the idea of the Communion, respondents clearly did think that their identities and the reputations of their parishes were significantly affected by the choices of Anglicans in distant places.

10.3 Although theologically liberal Anglicans in the global North have often been accused of acting without regard for the Communion, our data suggests a more complicated picture. Clearly some parishioners in the two parishes with strong gay profiles had limited interest in, or affection for, the Communion; however, a number expressed a hope for maintaining relationships with conservative Anglicans at home and abroad, and valued the idea of Anglicanism's diversity. However, if some of these respondents articulated visions for the Communion that resonated with Hassett's notion of diversity globalism (which she associates with the liberal/moderate position; see section 3), it was nevertheless clear that a willingness to remain in communion with conservatives did not universally equate with a total embrace of 'differences in culture, experience, and belief (Hassett 2007: 127). To some degree, the hope was ultimately to be able to assimilate difference rather than accommodate it indefinitely. Staying in communion with conservatives was discussed by some as a potential means through which anti-gay views could be changed, and thus had certain parallels with the form of accountability globalism invoked by some conservative respondents. In the parishes with more explicitly conservative theological leanings on homosexuality (particularly ACSA-2 and TEC-2), interest in the Anglican Communion was not obviously stronger than in the more liberal parishes, and although there was some hope that the Communion could call TEC and others 'to account', interest in the Communion was still often primarily 'theoretical' (section 9).

10.4 Future research on the Communion must attend closely to the complex interplay of localized and more extensive factors in the construction of Anglican identities and affiliations. For a number of our respondents across the case studies (particularly for many adult converts, but far from exclusively), debates in the Anglican Communion were a version of 'denominational politics', and denomination was a concept that was largely considered secondary to being Christian (see also Harris 1998). What many respondents identified as important was having a sense of 'comfort' within their local parishes - including particular styles of worship, ways of creating community, or, in some cases, stances on homosexuality. Broader events within the Communion have the potential to enhance or disturb these senses of comfort in local parishes in ways that have implications for the denominational affiliations of individuals and parishes -affiliations which a number of respondents described in contingent ways. Recent research in the US (e.g. Hoge and O'Connor 2004: 83) has highlighted the importance of differentiating analytically between 'denominational loyalty' and 'commitment to a local congregation'. A number of parishioners in each of our research contexts made this distinction explicit in their own narratives, with the presence of an international fellowship such as one finds in Anglicanism adding an additional dimension of complexity. Understanding the current and future direction of the international Communion requires examination of how Anglican identities and affiliations are constructed simultaneously within local contexts, national churches, and the wider discursive and material flows of the Communion. 


\section{Acknowledgements}

This article is dedicated to the memory of Steve de Gruchy, who showed great hospitality to the team during the South African fieldwork. Thanks also to Cindi Katz and Gerald West for their support in facilitating the fieldwork for this project. We are grateful for the support of a grant from the AHRC/ESRC Religion and Society Programme: 'Sexuality and Global Faith Networks' (AH/F009089/1). Thanks also to Paul Johnson for his critical reading of an earlier version of the manuscript, and for the comments of the editors and anonymous referees.

\section{Notes}

1 With thirty four autonomous provinces, the Anglican Communion claims about 80 million members worldwide. The Church of England is nominally the largest of the provinces, although the Church of Nigeria now boasts a greater number of actively practising Anglicans, reflecting both a decline in membership in the traditional Anglican core and the growth of a number of provinces in the global South (particularly on the African continent). The Archbishop of Canterbury officially acts as the Communion's 'focus of unity', but neither he nor any of the 'instruments of Communion' (such as the decennial Lambeth Conferences, where bishops gather to discuss issues of importance) have authority over the provinces, which have their own structures of governance. Rather, churches are linked by so-called 'bonds of affection' rooted in aspects of belief, liturgy, and a shared history often tied to British colonisation and missionary activity (see Ward 2006). Both within and between the provinces, there is a great diversity of styles of worship, with high church, broad church, and low church approaches.

2 The dissatisfaction of some Anglo-Catholics is often related to issues of female ordination and consecration as much or more than the acceptance of homosexuality. Of course, however, the history of TEC (as well as the South African Church; see Lewis 2007) has been heavily influenced by the AngloCatholic movement, and there is no essential Anglo-Catholic position on any of these issues.

3 See Ward (2006) on the theological and ecclesiological orientation of much writing on the Anglican Communion. Rowan Williams' Anglican Identities (2004) reflects on questions of the Communion through the writings of prominent Anglican theologians.

4 These excerpts are from Resolution DO25 (Commitment and Witness to Anglican Communion), passed at the 2009 General Convention of TEC. The resolution sought to affirm the church's commitment to the Communion but asserted the right of the province to ordain and consecrate gays and lesbians. Text of the resolution can be viewed at: <http://gc2009.org/ViewLegislation/view_leg_detail.aspx?id=986\&type=Final>.

5 This extract is from the paragraph 49 of the Windsor Report prepared in 2004 by the Lambeth Commission on Communion.

6 See Vanderbeck et al. (in press) for an extensive analysis of the activities of Robinson and pro-gay campaigning groups at Lambeth 2008.

7 This reading of St. Paul comes from the primates of the Council of Anglican Provinces of Africa in 2006 (quoted in Rubenstein 2008: 151)

8 The research is the result of the efforts of a five-person research team. All five researchers attended Lambeth 2008, while Sadgrove attended GAFCON and Vanderbeck and Andersson attended the 2009 General Convention of the Episcopal Church. Andersson conducted the US parish-level interviews, while Sadgrove collected the South African case study data. Andersson and Sadgrove collaborated in the parish interviews in England prior to embarking to the US and South Africa, respectively, with oversight from Valentine, Vanderbeck, and Ward. This allowed the five person research team to refine the approach to questioning while they were based together in England. However, close contact was maintained between the team members even when some were away in the US or South Africa, to ensure relative consistency in the themes explored during interviews, while also remaining flexible to the specificities of different contexts. All of the researchers identify as white Europeans or Americans. Although we will not present individual biographies here, the researchers represent a range of different positionalities in terms of Anglican (non)affiliation and sexual orientation. Researchers were sometimes asked about their own stances on the issues. Although members of the team were open in their support for LGBT human rights, it was emphasized that there was no official project position on the theological or ecclesiological dimensions of the debates. Particularly at ACSA-1, given South Africa's history, it was important to give consideration to our position as white European/American researchers in a South African township. Although some respondents in ACSA-1 seemed guarded in some of their responses, both Sadgrove and our local translator felt that overall the interviews were relatively candid in terms of perspectives on the Anglican Communion, given that respondents were willing to be critical of the North American and European provinces, as well as their local and provincial leadership. In TEC-2 it proved impossible to organise a group interview given the 
schedules of participants, so a larger number of individual interviews were held. See also Valentine et al. (2010) for further methodological reflections.

9 This proved particularly important in relation to ACSA-1, where interviews were conducted primarily in English (most of the parishioners were conversant in English) but with a Zulu translator from a local university also present so that respondents could express themselves in the Zulu language if they desired. After the interview and during transcription, dialogue was maintained with the translator about the meaning and context of exchanges that had to be translated. The quotations used here have not been translated.

10 In some cases, minor details have been altered to better protect participant anonymity.

11 This quotation does perhaps resonate with the frequent observation (e.g. Hassett 2007) that North Americans and Europeans tend to envision Africa as a continent of unrelenting, ubiquitous suffering, and, as such, the respondent is hinting that the horrors she imagines that 'these people have been through' have shaped their views.

12 This worry seems to assume that the Church of England would remain aligned with TEC rather than 'third world' churches, which is far from certain. It also assumes far too great a commonality of perspective amongst 'third world' countries. Brazil, for example, has shown little enthusiasm for an Anglican covenant.

13 This obviously also ignores the active participation of significant numbers of conservatives from the US, UK, Australia, and elsewhere in promoting 'traditional' views on homosexuality.

14 South African bishops have not been prominent in propagating anti-gay discourse; in fact, the opposite has often been true, most visibly in the case of retired Archbishop Desmond Tutu. Anglicans in Algeria are a tiny minority under the episcopal authority of the diocese of Egypt in the Episcopal Church in Jerusalem and the Middle East.

15 Although his suggestion here seems to reflect the frequent charge that liberal Episcopalians seek to use money to influence Communion relationships, it should be noted that several other respondents in the same group interview challenged the proposal to cut funding to Africa as 'un-Christian'.

16 Although group interview respondents in ACSA-1 expressed a clear desire for South Africa to take a more 'biblical' view, it is important to note that there was at least one self-identified lesbian who was relatively 'out' in the congregation and who expressed feeling generally comfortable there (individual interview). One respondent explicitly emphasised that any parent could unexpectedly have a gay child and this would present a dilemma, while another expressed that there was a need to heed New Testament messages about not being judgemental and not just Old Testament injunctions about sexuality.

17 The respondent is suggesting that 'Anglican' is the surname to the implicit first identity of 'Christian'.

18 It is important to note that issues of female ordination and gay ordination do not always map onto one another tidily. There are, for example, some conservative evangelicals who support women's leadership.

19 This outlook was by no means exclusive to those who had converted to an Episcopalian church. For example, Phillip (a white evangelical male at TEC-2) had been raised as an Episcopalian but went through a period of trying other kinds of churches. He came to TEC-2 because he liked the 'contemporary way of engaging with the liturgy and the worship' within the context of 'a robust faith community'. As he explained, 'I was not brought by Episcopal loyalties, but I was delighted that it was an Episcopal church.' Thus, although he valued his Episcopal heritage, he also did not make it the prime consideration in choosing a parish.

20 The respondent is referring to arguments that homosexual activity outside of marriage should be viewed as morally equivalent to heterosexual activity outside of marriage, although one could argue that the invocation of promiscuity here presents a problematic (although perhaps unintentional) form of stereotyping.

\section{References}

AMMERMAN, N.T. (2003) 'Religious Identities and Religious Institutions' in Dillon, M. (ed.) Handbook of the Sociology of Religion, Cambridge: Cambridge University Press, pp. 207-24.

BATES, S. (2004). A Church at War: Anglicans and Homosexuality. London and New York: I. B. Tauris.

CLATWORTHY, J. (2008) Liberal Faith in a Divided Church, Hants, UK: O Books.

COVENANT DESIGN GROUP (2009) The Anglican Communion Covenant. Available at:

<http://www.aco.org/commission/covenant/final/text.cfm>. 
CROCKETT, A. and Voas, D. (2003) 'A Divergence of Views: Attitude Change and the Religious Crisis over Homosexuality', Sociological Research Online, vol. 8, no. 4. Available at:

<http://www.socresonline.org.uk/8/4/crockett.html> [doi:10.5153/sro.861]

DOUGLAS, I.T. and Pui-Lan, K., eds. (2001) Beyond Colonial Anglicanism: The Anglican Communion in the Twenty-first Century. New York: Church Publishing.

GLEDHILL, R. And Combe, V. (2008) 'Gay Bishop's Row "Like Iraq War"'. The Times online. 20 July. Available at: <http://www.timesonline.co.uk/tol/comment/faith/article4364179.ece>

GLOBAL ANGLICAN FUTURES CONFERENCE (2008) Frequently asked questions. Available at: <http://www.GAFCON.org/info/faq>

. HARRIS, M. (1998) The Challenge of Communion: The Anglican Communion in the Postmodern Era, New York: Church Publishing.

HASSETT, M. (2007) Anglican Communion in Crisis: How Episcopal Dissidents and their African Allies are Reshaping Anglicanism, Princeton, NJ: Princeton University Press.

HOAD, N. (2007) African Intimacies: Race, Homosexuality, and Globalization, Minneapolis: University of Minnesota Press.

HOGE, D.R. and O'Connor, T.P (2004) 'Denominational Identity from Age Sixteen to Age Thirty-Eight' Sociology of Religion, Vol. 65, No. 1, pp. 77-85. [doi:10.2307/3712508]

KAYE, B. (2007) 'Is Sex Going to Kill the Anglican Communion?' Journal of Anglican Studies, Vol. 5, No. 7, pp. 7-9. [doi:10.1177/1740355307077928]

LEWIS, H.T. (2007) A Church for the Future: South Africa as the Crucible for Anglicanism in a New Century, New York: Church Publishing.

MCQUEENEY, K. (2009) "'We are God's Children, Y'all": Race, Gender, and Sexuality in Lesbian- and Gayaffirming Congregations' Social Problems Vol. 56, pp. 151-73. [doi:10.1525/sp.2009.56.1.151]

MUTTER, R. (2004) 'Doing the North-South Splits: Post-modern Strain on a Pre-modern Institution', Sociological Research Online, Vol. 9, No. 1. [doi:10.5153/sro.891]

O'DONOVAN, O. (2008) Church in Crisis: The Gay Controversy and the Anglican Communion . Eugene, OR: Cascade Books.

OROMBI, H. (2008) 'The Church Cannot Heal this Crisis of Betrayal', The Times Online. 1 August. Available at: <http://www.timesonline.co.uk/tol/comment/columnists/guest_contributors/article4438729.ece>

PICKARD, S. (2008) 'Introduction: National Anglican Identity Formation Project', Journal of Anglican Studies, Vol. 6, No. 9, pp. 9-16. [doi:10.1177/1740355308091382]

ROBERT, B. and Reddy, V. (2008) 'Pride and Prejudice: Public Attitudes Toward Homosexuality', Human Sciences Research Council Review, Vol. 6, No. 4. Available at:

<http://www.hsrc.ac.za/HSRC_Review_Article-121.phtml>

RUBENSTEIN, M.J. (2004) 'An Anglican Crisis of Comparison: Intersections of Race, Gender, and Religious Authority, with Particular Reference to the Church of Nigeria', Journal of the American Academy of Religion, Vol. 72, No. 2, pp. 341-65. [doi:10.1093/jaarel//fh033]

RUBENSTEIN, M.J. (2008) 'Anglicans in the Postcolony: On Sex and the Limits of Communion', Telos, Vol. 143, pp. 133-60.

SADGROVE, J., Vanderbeck, R.M., Ward, K., Valentine, G., and Andersson, J. (in press, 2010)

'Constructing the Boundaries of Anglican Orthodoxy: An Analysis of the Global Anglican Future Conference', Religion.

SMITH, C. (1998) American Evangelicalism: Embattled and Thriving, Chicago: University of Chicago Press.

SUGDEN, C. (2008) 'GAFCON Can Save Anglicanism.' The Guardian. July 3. Available at: <http://www.guardian.co.uk/commentisfree/2008/jul/02/religion.anglicanism>.

TE PAA, J. (2009) 'Jenny Te Paa Addresses the House of Deputies', Episcopallife Online, 12 July. Available 
at: http://www.episcopalchurch.org/107152_112408_ENG-HTM.htm.

THUMMA, S. and Gray, E.R., eds. (2005) Gay Religion, New York: AltaMira.

VALENTINE, G., Vanderbeck, R.M., Ward, K., Andersson, J., and Sadgrove, J. (2010) 'Researching Global Faith Networks: A Framework for Transcending Conventional Perspectives on International Comparative Research'. Paper presented at Innovative Methods in the Study of Religion. Sponsored by the AHRC/ESRC Religion and Society Programme and NORFACE. London, March 29.

VANDERBECK, R.M. (2006) 'Vermont and the Imaginative Geographies of American Whiteness', Annals of the Association of American Geographers, Vol. 96, No. 3, pp. 641-59. [doi:10.1111/j.1467-

8306.2006.00710.x]

VANDERBECK, R.M., Andersson, J., Valentine, G., Ward, K., and Sadgrove, J. (in press) 'Sexuality, Activism, and Witness in the Anglican Communion: the 2008 Lambeth Conference of Anglican Bishops', Annals of the Association of American Geographers .

WARD, K. (2006) A History of Global Anglicanism , Cambridge: Cambridge University Press.

[doi:10.1017/CBO9780511607509]

WILCOX, M.M. (2006) 'Outlaws or In-laws? Queer Theory, LGBT studies, and Religious Studies', Journal of Homosexuality, Vol. 52, No. 1, pp. 73-100. [doi:10.1300/J082v52n01_04]

WILLIAMS, R. (2004) Anglican Identities, London: Darton, Longman and Todd Ltd.

WILLIAMS, R. (2007) 'Why the Anglican Communion Matters', The Telegraph. 23 February. Available at: http://www.telegraph.co.uk/comment/personal-view/3637848/Why-the-Anglican-Communion-matters.html

WILLIAMS, R. (2009a) 'Communion, Covenant and our Anglican Future', 27 July. Available at: http://www.archbishopofcanterbury.org/2502

WILLIAMS, R. (2009b) A Message from the Archbishop of Canterbury on the Anglican Communion Covenant. Available at: <http://www.archbishopofcanterbury.org/2686>

YIP, A.K.T. (1997) 'Attacking the Attacker: Gay Christians Talk Back', British Journal of Sociology, Vol. 48, pp. 113-27. [doi:10.2307/591913]

YIP, A.K.T. (2005) 'Queering Religious Texts: An Exploration of British Non-heterosexual Christians' and Muslim's Strategies of Constructing Sexuality-affirming Hermeneutics', Sociology, Vol. 39: 47-65.

[doi:10.1177/0038038505049000]

YIP, A.K.T. and Keenan, M. (2004) 'By Name United, By Sex Divided: A Brief Analysis of the Current Crisis Facing the Anglican Communion', Sociological Research Online, Vol. 9, No. 1. Available at:

http://www.socresonline.org.uk/9/1/yip.html [doi:10.5153/sro.882] 